\title{
THE ORIGIN OF PROPERTY BUYERS IN POZNAŃ AND ITS SUBURBS1
}

\author{
Justyna Tanaś, PhD \\ Department of Controlling, Financial Analysis and Valuation \\ Poznań University of Economics \\ e-mail: justyna.tanas@ue.poznan.pl
}

\begin{abstract}
The market for land for single-family housing is one of the most important segments of the real estate market. Over the last several years, we have witnessed the development of this market in the suburban areas of large agglomerations. This is connected with the intensified migration of people from the centers of big cities, and with the development of housing in suburban zones.

The aim of this paper is to present the structure of the territorial origin of buyers purchasing plots designated for single-family housing in Poznań and its suburbs (with division into buyers derived from the city of Poznań, from the Poznań poviat (district), the Wielkopolska voivodeship (province), the rest of the country, and from abroad). The analysis covers the years 1995-2010.
\end{abstract}

Key words: the origin of the buyers of properties, the market for land plots, suburbanisation, Poznan agglomeration.

JEL Classification: R31.

Citation: Tanaś J., 2014, The origin of the buyers of properties in Poznan and its suburbs, Real Estate Management and Valuation, vol. 22, no. 2, pp. 5-12.

DOI: $10.2478 /$ remav-2014-0012

\section{Introduction}

The market for land for single-family housing is one of the most important segments of the real estate market. Over the last several years, we have witnessed the development of this market in the suburban areas of large agglomerations, which is the result of the suburbanization process (KRAJEWSKA 2010, GNAT, BAS 2013, TROJANEK 2013). This process is one of the features shared by contemporary European cities and their neighboring areas. It is mainly reflected in the outflow of wealthier population groups migrating from central districts of cities to their outskirts, from which they can easily commute to work in the city center. At the same time, these suburban areas offer much better living conditions than their inhabitants' previous place of residence. As a consequence, the number of inhabitants within the whole agglomeration increases, with the population of suburban areas growing faster than the population of central districts. At an advanced stage of suburbanization, the population of the central city actually decreases as a result of migration to the suburban zones (BERG 1981, KLAASSEN 1988, ZAGOŻDŻON 1988,CHAMPION 2001, ZUZIAK 2005).

Such processes can be also observed in Poznań and its suburbs. Since the 1990s, we have observed a steady drop in the number of people residing in the city of Poznań, accompanied by an increasing population of the gminas (communes) of the Poznań poviat. The main factor which contributed to the increase in the number of inhabitants within the poviat was the positive balance of migration from the central city (KACZMAREK 2012). The phenomenon under discussion has also been confirmed by an analysis conducted by A. WINIARCZYK - RAŹNIAK and P. RAŹNIAK - the typology of metropolitan areas based, among other things, on the migration balance and on the high mobility of the population

\footnotetext{
${ }^{1}$ The project was financed by National Science Center
} 
(WINIARCZYK - RAŹNIAK, RAŹNIAK 2012).

In this paper, we analyzed the structure of the origin of buyers who purchased land designated for single-family houses in the Poznan agglomeration in the years 1995-2010.

Notary deeds concerning transactions of the sale of non-built up land served as the main source of information used in the paper. Having studied the notary deeds from the repository of the Poviat Centre of Geodetic and Cartographic Documentation at the Poviat Starosty (District Governor's Office) in Poznań, we created a database including purchase and sale agreements concerning the sale transactions of non-built-up areas that were completed within the borders of the Poznan poviat in the years 1995-2010. From this base, we chose those transactions which referred to plots designated for single-family housing. We chose a set of 27,335 transactions for analysis. These had sufficiently cohesive market features to be used for the analysis of the fluctuations of land prices in the local market of the Poznań agglomeration. The database also included information about the territorial origin of land buyers.

\section{The scope of Poznań agglomeration}

An urban agglomeration is, first of all, a morphological unit and is composed of a compact set of settlement units (a large city with a suburban zone), which developed as a result of the processes of the concentration of built-up areas and functions in a city and its border zone. The territorial development of a city slows down (its administrative borders extend), while housing, industrial and service building development outside city borders acquires a more compact character (suburbanization) (KACZMAREK 2008).

From a practical point of view, it becomes necessary to establish such agglomeration borders which will remain unchanged over a longer period of time. Moreover, for legal and institutional reasons, agglomerations should be units of the state administrative division having legal authority over the assigned area, i.e. gminas (PARYSEK 2007).

On the basis of the analysis of previous studies (SWIANIEWICZ, KLIMSKA 2005, BEIM 2007, KACZMAREK 2008, PARYSEK 2008), as well as due to various social and economic conditions, it was assumed that the Poznań agglomeration covers the territory of the city of Poznan and the Poznan poviat, which includes 17 gminas in total.

\section{Analysis of the volume of transactions concerning land for single-family housing in the gminas of the Poznań poviat}

In the years 1995 - 2010, transactions concerning land for single-family housing took place in 253 of 283 precincts of the 17 gminas within the poviat. The biggest number of purchase and sale transactions was noted in the gminas of Kórnik, Dopiewo, Tarnowo Podgórne, Rokietnica and Swarzędz (over 9\% of all transactions within the Poznan poviat in 1995-2010), while the smallest number of such transactions was noted in the gminas of Buk, Puszczykowo and Lubon (below 3\%).

Figure 1 presents the share of transactions in a given gmina in the total number of transactions concerning land designed for single-family housing in the years 1995-2010. The volume of transactions concerning land purchase in the period under study was diverse and showed different tendencies. From the beginning of this period to 1999, the number of sold building plots in the Poznan poviat grew systematically. After 1999, the number of sold plots started to decrease. This phenomenon could be observed until 2002. In 2003, we witnessed an increase in the number of transactions of more than $65 \%$. This upward tendency continued until 2005, when the highest number of transactions took place - about $8.27 \%$ of the total number of completed transactions. This level was maintained in 2006 (8.26\% of transactions completed in the years 1995-2010), but the trend reversed in 2007, and the number of transactions began to systematically fall, dropping to the level of slightly above $5 \%$ of all transactions in 2010. The global recession in the middle of 2008 caused fluctuations in the real estate market concerning the number of completed transactions.

There was a very big interest in land designed for single-family housing in the Poznań agglomeration. When establishing local land management plans, the gminas adapted to the growing demand for specific kinds of land. The area of land of preferred use was also enlarged by excluding arable land from agricultural production and changing its designation. In this way, areas around Poznań obtained a lot of land with the desired functions; what is more, this land was cheaper than plots located in the centre of Poznań. Residents of the city of Poznań, motivated by lower land prices outside the city and by a wide choice of attractive locations, decided to buy plots on the territory of 


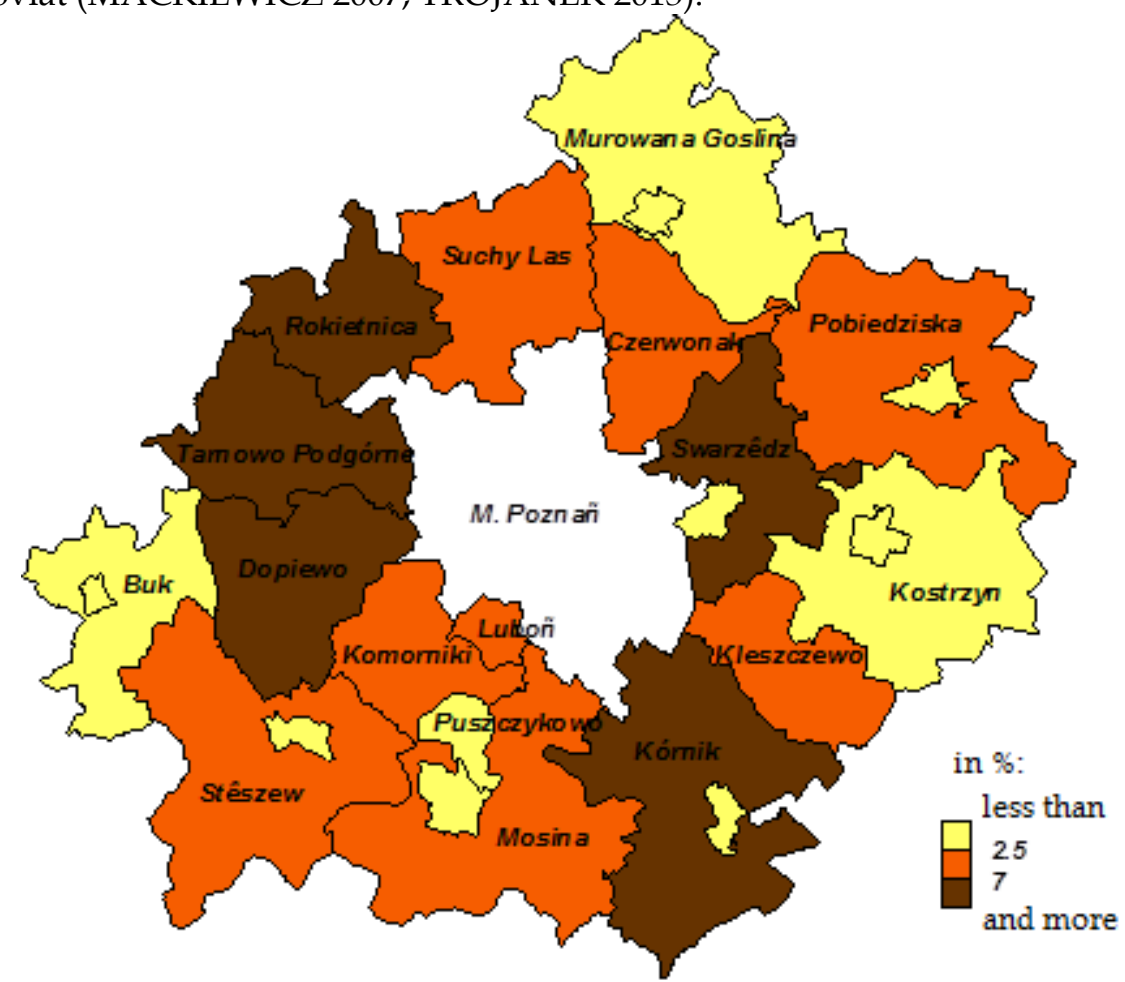

Figure 1. Share of transactions in a given gmina in the total number of transactions in the years 19952010. Source: Author's own work based on data gathered in the Poviat Center of Geodetic and Cartographic Documentation.

\section{The origin of buyers of building plots in the gminas of the Poznań poviat}

Since the beginning of the political transformation, we have observed a steady drop in the number of people residing in the city of Poznan. In the 15-year period under study, the size of the population decreased by over $5 \%$. This fact is, to a large degree, the result of the negative rate of natural increase (since 2006, the rate of natural increase has been positive). The decrease in population size, however, was intensified by the negative migration balance. In the same period, the number of people inhabiting the Poznań poviat went up by almost $36 \%$. Such a big increase in population size in the suburban areas of Poznan was, first of all, the result of a positive migration balance. A lot of new inhabitants of the gminas of the Poznan poviat had to first buy a land property.

Table 1 and diagram 1 show the structure of the origin of buyers of land designed for single-family housing in the gmina of the Poznań poviat.

Table 1

The structure of the origin of buyers of land designed for single-family housing in the gminas of the Poznań poviat in the years 1995-2010.

\begin{tabular}{lcccccc}
\hline Gmina & Poznań & gmina & poviat & voivodeship & country & abroad \\
\hline Buk & $19.53 \%$ & $64.19 \%$ & $5.81 \%$ & $9.07 \%$ & $0.93 \%$ & $0.47 \%$ \\
Czerwonak & $57.96 \%$ & $23.89 \%$ & $8.30 \%$ & $4.28 \%$ & $4.97 \%$ & $0.60 \%$ \\
Dopiewo & $68.12 \%$ & $12.78 \%$ & $9.77 \%$ & $5.33 \%$ & $3.84 \%$ & $0.16 \%$ \\
Kleszczewo & $53.69 \%$ & $11.58 \%$ & $16.61 \%$ & $10.74 \%$ & $7.05 \%$ & $0.34 \%$ \\
Komorniki & $58.90 \%$ & $20.34 \%$ & $10.51 \%$ & $5.68 \%$ & $4.32 \%$ & $0.25 \%$ \\
Kostrzyn & $38.76 \%$ & $21.71 \%$ & $20.49 \%$ & $13.73 \%$ & $5.09 \%$ & $0.22 \%$ \\
Kórnik & $63.53 \%$ & $10.99 \%$ & $8.58 \%$ & $10.31 \%$ & $6.04 \%$ & $0.54 \%$ \\
Luboń & $36.81 \%$ & $53.41 \%$ & $4.69 \%$ & $2.41 \%$ & $2.54 \%$ & $0.13 \%$ \\
Mosina & $37.27 \%$ & $32.98 \%$ & $18.02 \%$ & $6.37 \%$ & $4.45 \%$ & $0.92 \%$ \\
Murowana Goślina & $51.90 \%$ & $26.70 \%$ & $10.93 \%$ & $5.06 \%$ & $3.80 \%$ & $1.61 \%$ \\
Pobiedziska & $61.13 \%$ & $17.46 \%$ & $10.43 \%$ & $6.02 \%$ & $4.68 \%$ & $0.28 \%$ \\
Puszczykowo & $50.12 \%$ & $25.65 \%$ & $12.00 \%$ & $6.12 \%$ & $4.71 \%$ & $1.41 \%$ \\
\hline
\end{tabular}




\begin{tabular}{lllllll}
\hline Rokietnica & $66.22 \%$ & $9.55 \%$ & $12.01 \%$ & $6.71 \%$ & $4.95 \%$ & $0.56 \%$ \\
Stęszew & $46.37 \%$ & $24.95 \%$ & $16.70 \%$ & $6.04 \%$ & $5.16 \%$ & $0.77 \%$ \\
Suchy Las & $66.37 \%$ & $19.12 \%$ & $4.41 \%$ & $6.67 \%$ & $3.24 \%$ & $0.20 \%$ \\
Swarzędz & $45.89 \%$ & $38.26 \%$ & $4.62 \%$ & $6.53 \%$ & $4.53 \%$ & $0.17 \%$ \\
Tarnowo Podgórne & $60.77 \%$ & $19.01 \%$ & $6.13 \%$ & $5.99 \%$ & $7.16 \%$ & $0.95 \%$ \\
Powiat poznański & $56.09 \%$ & $21.76 \%$ & $9.92 \%$ & $6.86 \%$ & $4.85 \%$ & $0.51 \%$ \\
\hline
\end{tabular}

Source: Same as Figure 1.

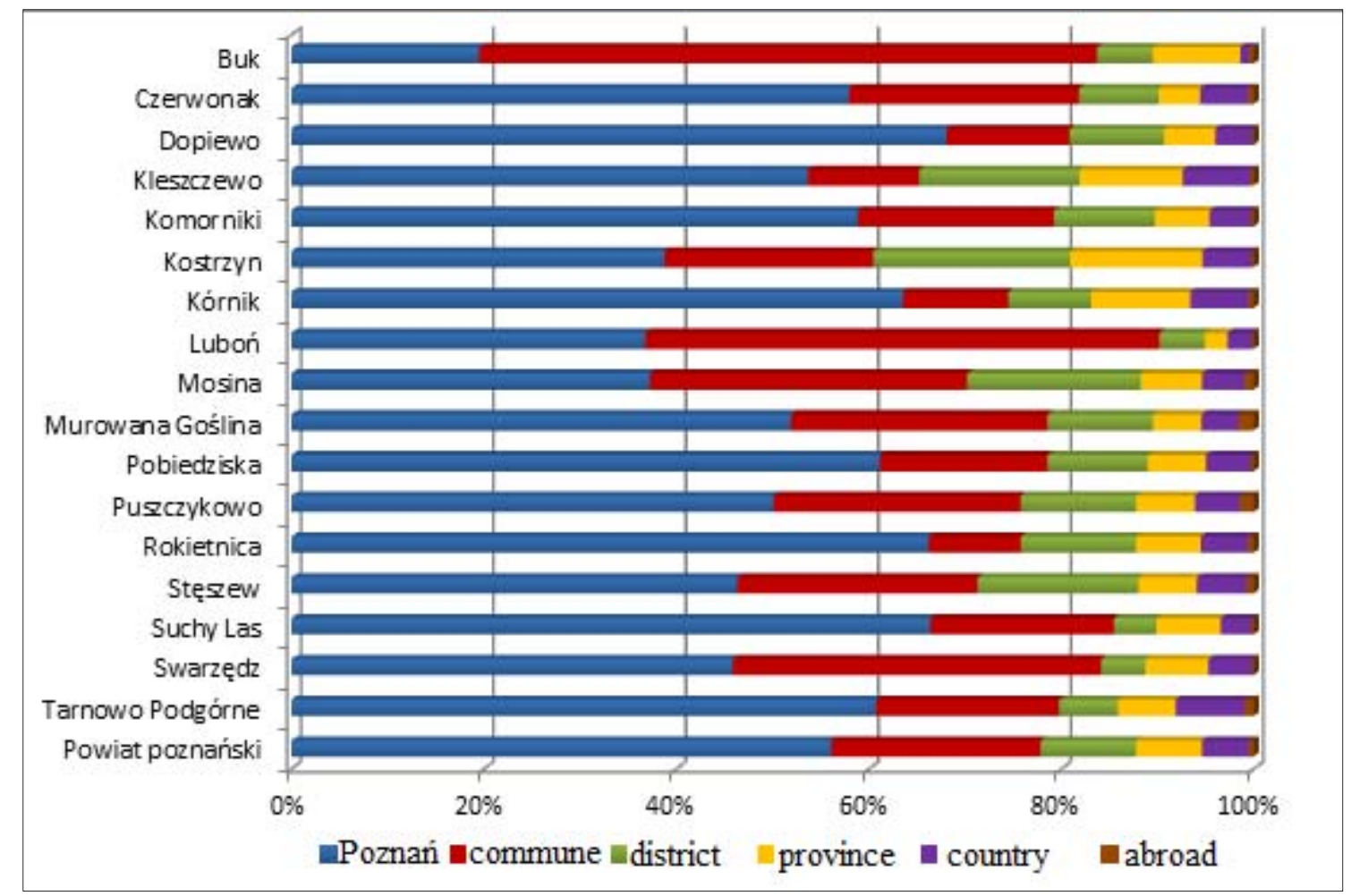

Diagram 1. The structure of the origin of buyers of land designed for single-family housing in the gminas of the Poznan poviat in the years 1995-2010. Source: same as Figure 1.

The analysis of the structure of the origin of people who bought land in the area of the Poznan poviat in 1995-2010 shows that most of them were inhabitants of Poznan (over 56\%). They represented the dominant portion of buyers in terms of the number of purchased plots, their size and value. The next group of buyers were the inhabitants of the gmina where the plot was located (every fifth plot). Every tenth plot was bought by citizens of other gminas within the Poznan poviat. Buyers from the remaining poviats of the Wielkopolska voivodeship accounted for $7 \%$ of the total, while people from other voivodeships bought just under $5 \%$ of the plots. Residents of other countries represented the least numerous group of buyers of land in the suburban zone of Poznań.

Buyers from the city of Poznań dominated the market in most gminas, with the exception of Buk and Luboń. In these gminas, plots were most often bought by their own inhabitants. Foreign buyers were most willing to purchase real estate in the gminas of Murowana Goślina $(1.61 \%)$ and Puszczykowo $(1.41 \%)$, while people from other voivodeships were interested in plots located in the gminas of Kleszczewo (7.05\%), Kórnik (6.04\%), Stęszew (5.16\%) and Kostrzyn (5.09\%).

Figure 2 presents the number of plots in the Poznański poviat purchased by the residents of the city of Poznań.

In the period under study, the residents of Poznań city most often bought plots in the gminas of Kórnik (14.09\% of all transactions in which a Poznań city inhabitant was the buyer), Dopiewo $(12.08 \%)$, Rokietnica $(11.58 \%)$, Tarnowo Podgórne (10.15\%), Pobiedziska $(8.25 \%)$ and Swarzędz $(8.15 \%)$. Transactions completed in the gminas of Buk $(0.63 \%)$, Puszczykowo $(1.60 \%)$, Lubon $(2.07 \%)$ and Kleszczewo $(2.41 \%)$ constituted a relatively small proportion of the total number of plots purchased by the inhabitants of the city of Poznan. 


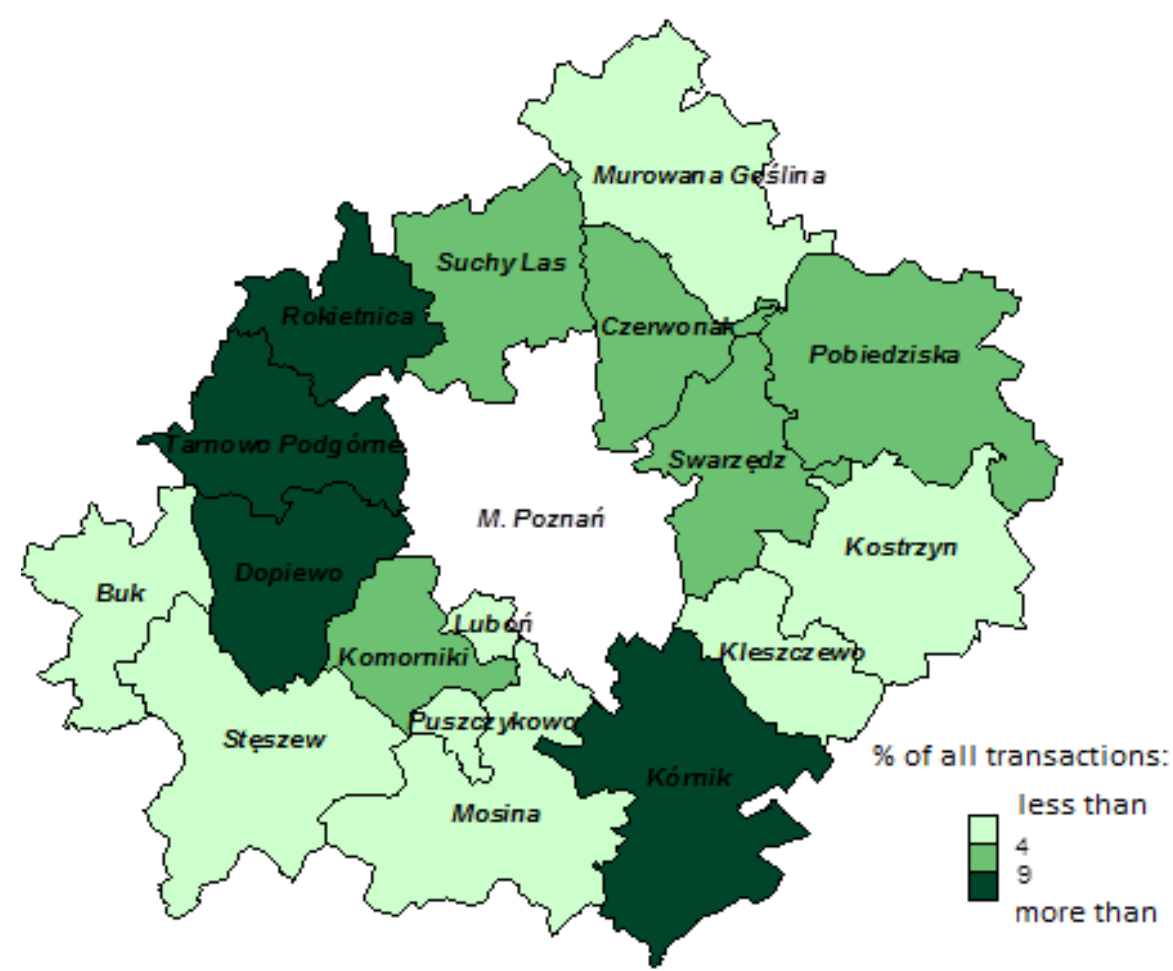

Figure 2. Land real estate bought by the residents of the city of Poznan within the gminas of the Poznań poviat in the years 1995-2010. Source: same as Figure 1.

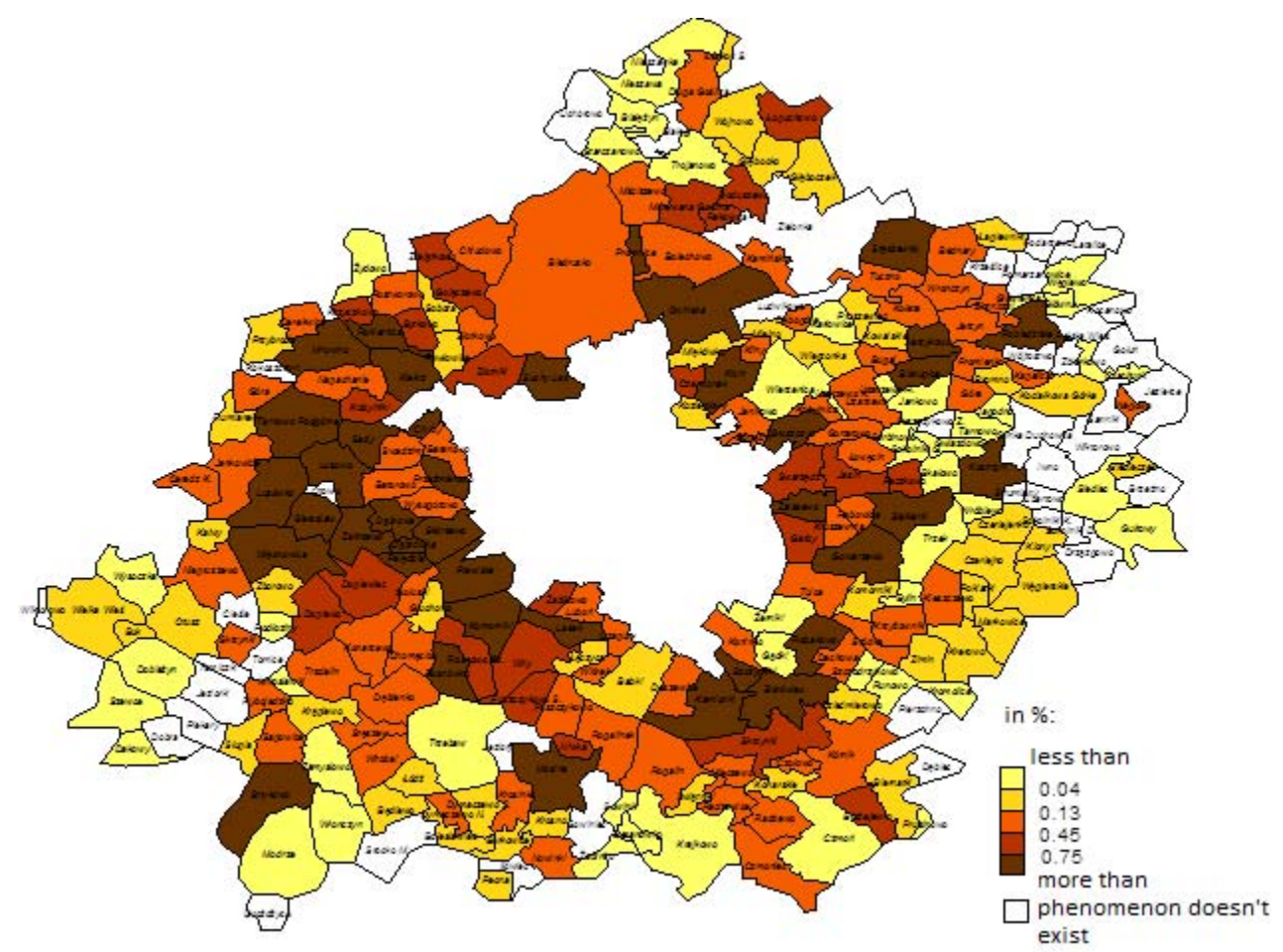

Figure 3. Land real estate properties purchased by the inhabitants of the city of Poznan in the particular precincts of the Poznan poviat in the years 1995-2010. Source: same as Figure 1.

Figure 3 shows the proportion of transactions in which the inhabitants of Poznań were the buyers in the particular precincts.

The residents of the city of Poznań showed different degrees of interest in the purchase of building plots within the territories of particular gminas. The highest number of transactions with buyers from the city took place in the precincts directly neighboring the city, as well as in the somewhat more distant towns of the gminas of Tarnowo Podgórne and Rokietnica. The most popular towns among 
the residents of the city of Poznań who decided to purchase plots included Rokietnica, Kiekrz (gmina of Rokietnica), Skórzewo, Dąbrowa (Dopiewo), Suchy Las, Chyby (Tarnowo Podgórne), Kamionki, Borówiec and Szczytniki (Kórnik). Transactions completed in these nine precincts accounted for 28\% of the total number of transactions in which the buyer was a resident of the city of Poznań. People from the city were the least interested in plots located in towns that are the most distant from the city. Among the towns in which there were no transactions with the participation Poznań city residents, the external gminas of the poviat (i.e., Kostrzyn, Pobiedziska, Stęszew, Murowana Goślina and Buk) were the most common.

Diagram 2 shows the share of the area of plots within particular gminas in the total size of land real estate properties purchased by the residents of Poznań city.

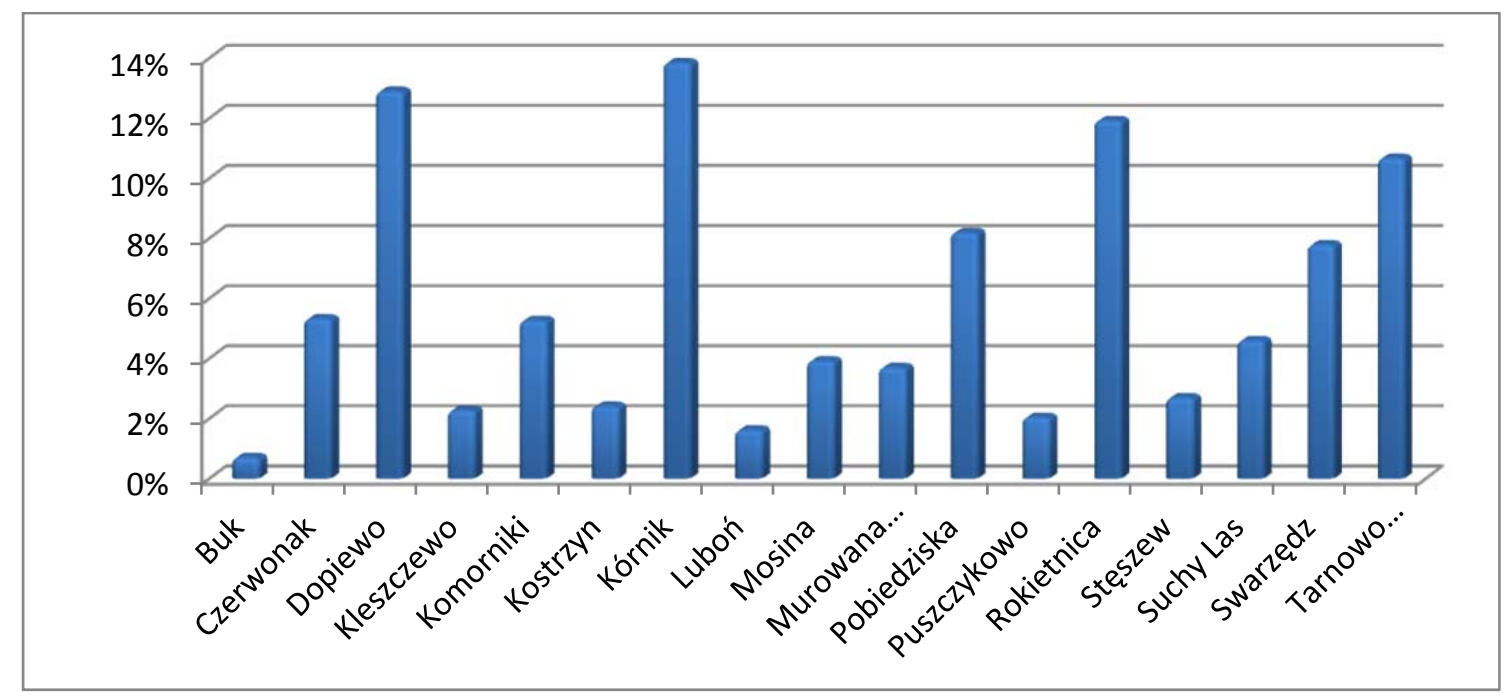

Diagram 2. The size of land purchased by the residents of the city of Poznan in the gminas of the Poznan poviat in the years 1995-2010. Source: same as Figure 1.

The analysis of the size of purchased plots in the individual gminas shows that the total area of plots bought by the residents of Poznań city was quite diverse. Four gminas (Kórnik, Dopiewo, Rokietnica and Tarnowo Podgórne) accounted for almost 50\% of the total sales volume. Poznań city residents became the owners of almost 190 ha of residential land in Kórnik, nearly 180 ha in Dopiewo, over 160 ha in Rokietnica, and close to 150 ha in Tarnowo Podgórne. Gminas with the smallest total area of plots purchased by residents of the city of Poznań include Buk (just under 10 ha), Lubon (slightly over 22 ha) and Puszczykowo (approx. 28 ha).

The fact that the inhabitants of Poznan purchased land meant that capital flowed to the sellers of these properties. Figure 4 shows the value of the completed transactions, taking into consideration the price and size of properties in the particular gminas.

The above figure shows that the biggest flow of capital connected with the purchase of land by people coming from the city of Poznan concerned the same gminas for which the total area of the plots sold was the biggest. The turnover value on the territory of these gminas was respectively: Tarnowo Podgórne - over 105 million zlotys, Dopiewo - over 105 million zlotys, Kórnik - about 100 million zlotys, Rokietnica - about 82 million zlotys. The inhabitants of Poznan invested the smallest amount of capital in land located in Buk (slightly over 3 million zlotys), Stęszew (almost 12 million zlotys) and Luboń (about 15 million zlotys).

\section{Conclusion}

The analysis of the origin of buyers of land designed for single-family housing in the Poznan agglomeration has indicated a strong connection of the city of Poznan with the gminas of the Poznan poviat.

Our analysis has shown that the residents of the city of Poznan were the most frequent buyers of land designed for single-family housing in Poznan and its suburbs in the years 1995-2010. They represented the dominant group of buyers in terms of the number of purchased plots, as well as their size and value. This phenomenon is a reflection of the process of suburbanization within the Poznan 
agglomeration. The next most frequent group of buyers comprised the inhabitants of the gmina where the purchased plot was located (every fifth plot). Residents of the remaining part of the Wielkopolska voivodeship those from the rest of the country and citizens of other countries represented the least numerous groups of buyers of land in the suburban zone of Poznań.

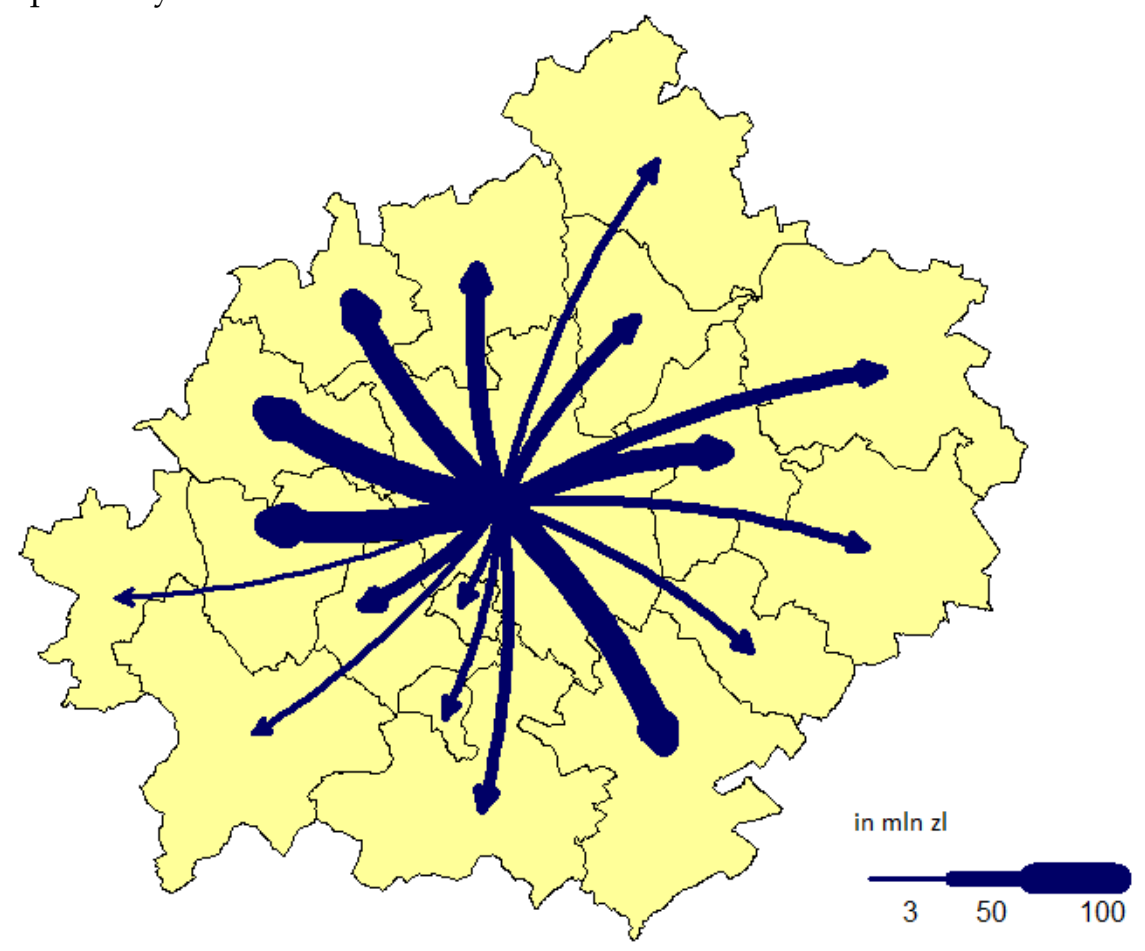

Figure 4. The value of land bought by the residents of the city of Poznan in the gminas of the Poznan poviat in the years 1995-2010. Source: same as Figure 1.

The residents of the city of Poznań were particularly interested in plots located in gminas directly neighboring Poznań, while those in gminas more distant from the city were not found to be nearly as attractive. Poznań city residents tended to buy land in gminas west of the city (Dopiewo, Rokietnica and Tarnowo Podgórne). The reason for this is the fact that the western side of the city is traditionally believed to be more conducive to the development of housing functions.

The phenomenon under discussion is the result of the suburbanization process. As far as social phenomena are concerned, suburbanization is not a favorable phenomenon. The scale and dynamics of the process encourages us to observe this phenomenon more closely since it brings about many negative consequences. Hence, suburbanization should be subject to close scrutiny and the development of suburbs ought to become the priority issue of spatial planning.

\section{References}

BEIM, M., 2007, Modelowanie procesu suburbanizacji w aglomeracji poznańskiej z wykorzystaniem sztucznych sieci neuronowych i automatów komórkowych, praca doktorska, (Modelling the Process of Suburbanisation in Poznan Agglomeration with the Application of Artificial Neural Networks and Cellular Automatons, PhD thesis).

BERG VAN DEN, L., DREWETT, R., KLAASSEN, L.H., ROSSI, A., VIJVERBERG, C.H.T., 1982, Urban Europe. A study of growth and decline, Pergamon Press, Oxford.

CHAMPION, T., 2001, Urbanization, suburbanization, counterurbanization and reurbanization, w: PADDISON, R. (red.,) Handbook of urban studies, Sage Publications, London, s. 143-161.

GNAT S., BAS M., 2013, "Statistical analysis of chosen aspects of suburbanisation process in Szczecin in 2006-2001", Real Estate Management and Valuation, vol. 21, no. 3, pp. 71-80.

KACZMAREK, T., 2008, Aglomeracja miejska jako region badania i działania, (Urban Agglomeration as a Field of Study and Activity) w: KACZMAREK, T., MIZGAJSKI, A., (red.), Powiat poznański. Jakość przestrzeni i jakość życia (The Poznań Poviat. The Quality of Space and the Quality of Living), Bogucki Wydawnictwo Naukowe, Poznań, s. 15-36. 
KACZMAREK, T., (red.) 2012, Studium uwarunkowań rozwoju przestrzennego aglomeracji poznańskiej (The Study of the Determinants of the Spatial Development of Poznań Agglomeration), Centrum Badań Metropolitalnych, Poznań.

KLAASSEN, L.H., 1988, Myśl i praktyka ekonomiczna a przestrzeń (Economical Thought and Practice), Wydawnictwo Uniwersytetu Łódzkiego, Łódź.

KRAJEWSKA, M., 2010, Analiza zmian wartości gruntów w strefach podmiejskich dużych miast (The Analysis of Changes in the Value of Land in the Suburban Zones of Large Cities), w: ŹRÓBEK, S., (red.), Studia i materiały Towarzystwa Naukowego Nieruchomości, Volume 18, Number 3, Olsztyn, s. 51-60.

MAĆKIEWICZ, B., 2007, Rynek nieruchomości niezabudowanych w Poznaniu i powiecie poznańskim w latach 1995 - 2000 (The Market for Non-Built Up Real Estate in Poznań and the Poznań Poviat in 1995-2000) , Bogucki Wydawnictwo Naukowe, Poznań.

PARYSEK, J. J., 2008, Procesy suburbanizacyjne w aglomeracji poznańskiej (Suburbanisation Processes in Poznań Agglomeration) w: KACZMAREK, T., MIZGAJSKI, A., (red.), Powiat poznański. Jakość przestrzeni i jakość życia (The Poznań Poviat. The Quality of Space and the Quality of Living), Bogucki Wydawnictwo Naukowe, Poznań, s. 71-90.

SWIANIEWICZ, P., KLIMSKA, U., 2005, Społeczne i polityczne zróżnicowanie aglomeracji w Polsce waniliowe centrum, mozaika przedmieść (Social and Political Differnetiation of Agglomerations in Poland - Vanilla Centres and the Mosaic of Suburbs), Prace i Studia Geograficzne, t. 35, Warszawa, s. $45-70$.

TROJANEK, R., 2013, Buyers at the housing market of Poznan, in: Actual Problems of Economics 2013 nr 12/150, National Academy of Management. s. 535-543.

WINIARCZYK - RAŹNIAK, A., RAŹNIAK, P., 2012, Migracje wewnętrzne ludności w polskich obszarach metropolitalnych $\mathrm{u}$ progu XXI wieku (Internal Migrations of the Population), Wydawnictwo Naukowe Uniwersytetu Pedagogicznego, Kraków.

ZAGOŻDŻON, A., 1988, Sieć osadnicza, zmienność i trwałość (The Settlement Network, Changeability and Durability), w: JAŁOWIECKI B., KALTENBERG-KWIATKOWSKA E. (red.) Proces urbanizacji i przekształcenia miast $\mathrm{w}$ Polsce (The Process of the Urbanisation and Transformation of Cities in Poland), Ossolineum, Wrocław-Warszawa.

ZUZIAK, Z., 2005, Strefa podmiejska w architekturze miasta. W stronę nowej architektoniki regionu Miejskiego (The Subarban Zone in the Architecture of the City. Towards the New Architectonics of the Urban Region), w: LORENS, P. (red.,) Problem suburbanizacji (The Suburbanisation Problem), Biblioteka Urbanisty 7, Urbanista, Warszawa, s. 17-32. 